\title{
Comparison of Holstein, Charbray, and Zebu Bulls for beef production under rotational grazing II. Offal components and carcass composition'
}

\author{
Américo Casas ${ }^{2}$, Danilo Cianzio ${ }^{3}$ and Aixa Rivera
}

J. Agric. Univ. P.R. 81(3-4):115-124 (1997)

\begin{abstract}
After two complete grazing trials, 47 Holstein, Charbray and Zebu (mostly Brahman) bulls were processed for offal components, carcass traits and composition comparisons at an average liveweight (LW) of $545 \mathrm{~kg}$. At the same LW the Holstein bulls had a significantly higher $(P<0.05)$ weight for the head $(3.33 \%$ of $L W)$, feet $(2.47 \%$ of $L W)$, liver $(1.11 \%$ of $L W)$, kidneys $(1.29 \%$ of LW) and intestines $(5.18 \% \mathrm{LW})$ than the Zebu and Charbray bulls, and a significantly longer leg $(53.0$ vs. $48.90 \mathrm{~cm} ; P<0.05)$ than the Charbray bulls. The Zebu bulls had the heaviest hide $(P<0.05)$ and smallest stomach weight $(P<0.05)$. The carcasses of the Holstein bulls had a significantly higher $(P<0.05)$ bone percentage $(21.60$ vs. $16.63,17.46 \%)$ and a lower amount of fat than the Charbray and Zebu bulls, respectively. Charbray bulls presented greater loin eye area, total amount of muscle, muscle to bone+fat ratio and weight and percentage of the Biceps femoris, Gluteus, and Cuadriceps femoris muscles in the left-hindquarter ( $\mathrm{LH}$ ), than the Zebu and Holstein bulls $(P<0.05)$. Charbray and Zebu bulls showed greater $(P<0.05)$ thickness of the round $(26.03,25.85$, vs. $24.03 \mathrm{~cm})$, hot carcass and $\mathrm{LH}$ weight, total dissectible fat, dressing percentage, muscle to bone ratio, and weight of the Semimembranosus, Psoas major, Longissimus dorsi and Semitendinosus muscles than the Holstein bulls $(P<0.05)$. No significant differences $(P>0.05)$ were found among breeds for subcutaneous fat thickness and for the weights of fascia/tendon, trimming, carcass shrinkage, and for the forequarter weight and percentage of left side.
\end{abstract}

Key words: dairy beef, Holstein bulls, offal components, carcass composition

'Manuscript submitted to the Editorial Board 24 February 1997.

'Assistant Animal Nutritionist, Department of Animal Industry, P.O. Box 21360, Río Piedras, P.R. 00928.

Professor, Department of Animal Industry.

Extension Beef Specialist, Department of Animal Industry. 


\author{
RESUMEN \\ Comparación de toros Holando, Charbray y Cebú para producción de carne \\ bajo pastoreo rotacional \\ II. Componentes del animal muerto y composición de la canal
}

Cuarenta y siete toros de las razas Holando, Charbray y Cebú (mayormente Brahman) engordados bajo pastoreo rotacional se procesaron para carne a un peso vivo promedio de $545 \mathrm{~kg}$ para determinar diferencias en los componentes del animal muerto y las caracteristicas y composición de la canal. A un mismo peso vivo de matanza (PM), los toros Holando tuvieron pesos mayores $(P<0.05)$ de la cabeza $(3.33 \%$ del $P M)$, extremidades $(2.47 \%$ del PM), hígado (1.11\% del PM), riñones (1.29\% del PM) e intestinos $(5.18 \%$ del PM) que los toros Cebú y Charbray y una mayor longitud de pierna (53.0 vs. $48.90 \mathrm{~cm} ; \mathrm{P}<0.05)$ que los toros Charbray. Los toros Cebú tuvieron el cuero más pesado $(\mathrm{P}<0.05)$ y el peso menor de estómago $(\mathrm{P}<0.05)$. Las carcasas de los toros Holando tuvieron porcentajes significativamente mayores $(P<0.05)$ de hueso $(21.60$ vs. $16.63,17.46 \%)$ y un contenido menor de grasa separable que las de los toros Charbray y Cebú, respectivamente. Los toros Charbray presentaron mayor $(P<0.05)$ area del músculo Longissimus, cantidad total de músculo, razón de músculo a hueso+grasa y peso y porcentaje de los músculos Biceps femoris, Gluteus y Cuadriceps femoris del cuarto trasero izquierdo, que los toros Cebú y Holando. Además, los toros Charbray y Cebú tuvieron un mayor $(P<0.05)$ ancho de pierna $(26.03,25.85$, vs $24.03 \mathrm{~cm}$ ) porcentaje de rendimiento, peso de carcasa caliente y cuarto trasero izquierdo, razón de músculo a hueso y peso de los músculos Semimembranosus, Psoas major, Longissimus dorsi y Semitendinosus que los toros Holando. No se encontraron diferencias significativas entre las razas para el espesor de grasa subcutánea, peso promedio del tejido conectivo, músculo de descarte, merma de la carcasa en nevera y para el peso y porcentaje del cuarto delantero de la canal izquierda.

\title{
INTRODUCTION
}

Large dairy breeds are late maturing and can reach heavier mature weight and larger size. Animals of large mature size have a longer period of straight line growth during which they show a greater rate of weight increase than animals of smaller mature size. When evaluated at same weight or age, breed types differing in growth rate will be at, different points of their gxow th curve and at a different physiological age. Therefore, for true comparisons of carcass traits and composition among breeds of large, medium, and small mature weights it is more appropriate to have them similar in physiological age or degree of fatness, rather than chronological age or weight.

However, when the main objective is to compare breeds from a practical standpoint, comparisons should take place under the same environment, and animals should be slaughtered at standard market processing weights. This is particularly true for countries like Puerto Rico, where there is no grading system and cattle are fed to a final desirable weight and not to a final degree of fatness. In this case, there is no premium paid for finishing cattle, and feeding to a final degree of fatness would only rosult in an increase of production costs. 
It has been established that Holstein steers produce carcasses with similar or higher cutting yields than steers from British beef breeds (Callow, 1961; Carroll et al., 1964; Cole et al., 1964; García-Siles et al., 1977; Kidwell and McCormick, 1956; Nour et al., 1983b; Thonney et al., 1984, 1991; Truscott et al., 1976) and can reach the industry standard of choice quality grade and produce carcasses with as many or more boneless retail cuts at current fat trim levels (Knapp et al., 1989; Nour et al, 1983a; Thonney et al., 1987; Ziegler et al., 1971). Moreover, the sensory attributes of beef from Holstein steers have been reported as adequate, and the differences in overall acceptability of limited commercial relevance (Armbruster et al., 1983; Thonney et al., 1991; Ziegler et al., 1971).

The afore mentioned studies compared carcass traits, composition, cutability, and meat quality of dairy and British breeds, mainly from steers at high planes of nutrition. Very little research has evaluated the meat production potential of Holstein bulls against large, late maturing and heat tolerant beef breeds under grass based systems in tropical environments. The present study involves a comparison between purebred Holstein, Charbray and Zebu bulls slaughtered at similar final weights for offal components, and carcass traits and composition comparisons.

\section{MATERIALS AND METHODS}

Between May 1991 and January 1995 the grazing performance of 87 Holstein, Charbray and Zebu type (mostly Brahman) bulls was evaluated in two grazing trials. Forty-seven bulls of similar final weights were selected from these groups to determine differences in offal components, and carcass traits and composition among breed-types. The bulls were processed into beef and the experimental data was collected at the Lajas Research Station slaughterhouse.

Among the offal components separated and weighed were the head, feet, tail, hide, kidneys, liver, heart, stomach, and intestines. Dressed carcasses were weighed before washing and again after chilling to determine dressing percentage and carcass shrinkage. Dressing percentages were calculated by using the last on farm liveweight. After processing, the carcasses were chilled for 20 to 22 hours at 2 to $4^{\circ} \mathrm{C}$ and the left sides were then quartered between the 12th and 13th rib and weighed.

Carcass measurements included ribeye area, subcutaneous fat thickness at 12 th rib, and length and width of the left hind leg. The left hindquarter was dissected into muscle, fat, bone, and fascia/tendon (connective tissue) groups. The bones were closely trimmed and the 
trimming divided into muscle, fat, and connective tissue. Fat, bone, muscle, connective tissue, and trimmed products were weighed and one-inch-thick steaks from the Psoas major, Longissimus dorsi, Biceps femoris, Gluteus, Semimembranosus, Quadriceps femoris, and Semitendinosus muscles were saved, wrapped, and frozen for further meat quality determinations.

All dependent variables evaluated were analyzed by the Analysis of Covariance Procedure from SAS (1987). Processing and hot carcass weight, left-side and left-hindquarter weight, and total muscle weight of the left hindquarter were used as covariates to adjust for differences when comparing offal components, carcass traits, left hindquarter weight and component tissues, and excised muscles of the left hindquarter among breeds. The model included an overall mean and the main effects of year, breed and their interaction. The Duncan Multiple Range test was used to compare differences among treatment means.

\section{RESULTS AND DISCUSSION}

\section{Offal components}

Table 1 presents the mean weights and percentages of liveweight (CW) by breed for the hide, head, heart, liver, kidneys, feet, tail, stomach, and intestines. When compared at the same processing weight, Holstein bulls had a significantly higher $(\mathrm{P}<0.05)$ weight for the head $\{3.33 \%$ of $\mathrm{LW}$ ), feet (2.47\% of LW), liver ( $1.11 \%$ of LW), kidneys ( $1.29 \%$ of LW), and intestines (5.18\% LW) than the Zebu and Charbray bulls. These data agree with those of Truscott et al. (1976) who reported that at the same offal weight Friesians steers had heavier feet and intestines $(+0.55$ and $+2.43 \mathrm{~kg})$ than Angus steers. Harte and Conniffe (1967) reported that Friesians had greater weights for most offal components than Angus and Hereford crosses when compared at similar weights; however, there were no significant differences between breeds in the weights of the intestines at similar empty body weights.

The Zebu bulls had the heaviest hide $(9.06 \%$ ) of the three breeds ( $\mathrm{P}$ $<0.05$ ) and a significantly smaller stomach weight than the Holsteins. In agreement with these findings, Carpenter et al. (1961) and Terry et al. (1990) reported that Bos indicus cattle had the highest percentage of their LW as hide, smaller stomachs $(\mathrm{P}<0.05)$, and that the liver was the only major edible by-product that differed significantly among En-

glish, Zebu crosses, and Holstein steers, with Holstein cattle having the highest percentage of their LW as liver. In the present study the Charbray and Zebu bulls showed no significant difference $(P>0.05)$ for the weight of the head ( 3.06 vs. $2.91 \%$ of LW), intestines ( 3.73 vs. $3.17 \%$ of 
TABLE 1.-Mean weight and percentage of liveweight of offal components of Holstein, Charbray and Zebu bulls.'

\begin{tabular}{lcccccc} 
& \multicolumn{2}{c}{ Holstein } & \multicolumn{2}{c}{ Charbray } & \multicolumn{2}{c}{ Zebu } \\
\cline { 2 - 7 } Item & $\mathrm{kg}$ & \% of $\mathrm{LW}$ & $\mathrm{kg}$ & $\%$ of LW & $\mathrm{kg}$ & \% of LW \\
\hline Green Hide & $38.32 \mathrm{c}^{2}$ & 6.84 & $46.02 \mathrm{~b}$ & 8.09 & $52.12 \mathrm{a}$ & 9.06 \\
Whole head & $18.79 \mathrm{a}$ & 3.33 & $17.43 \mathrm{~b}$ & 3.06 & $16.75 \mathrm{~b}$ & 2.91 \\
Stomach & $25.74 \mathrm{a}$ & 4.60 & $23.08 \mathrm{ab}$ & 4.05 & $19.68 \mathrm{~b}$ & 3.42 \\
Intestines & $29.01 \mathrm{a}$ & 5.18 & $21.23 \mathrm{~b}$ & 3.73 & $18.23 \mathrm{~b}$ & 3.17 \\
Feet & $13.87 \mathrm{a}$ & 2.47 & $10.60 \mathrm{~b}$ & 1.86 & $11.29 \mathrm{~b}$ & 1.96 \\
Tail & $1.07 \mathrm{a}$ & 0.19 & $1.04 \mathrm{a}$ & 0.18 & $1.01 \mathrm{a}$ & 0.18 \\
Heart & $1.96 \mathrm{a}$ & 0.35 & $1.97 \mathrm{a}$ & 0.35 & $1.85 \mathrm{a}$ & 0.32 \\
Liver & $6.24 \mathrm{a}$ & 1.11 & $5.86 \mathrm{~b}$ & 1.03 & $5.72 \mathrm{~b}$ & 0.99 \\
Kidneys & $1.29 \mathrm{a}$ & 0.23 & $1.01 \mathrm{~b}$ & 0.18 & $0.92 \mathrm{~b}$ & 0.16 \\
\hline
\end{tabular}

${ }^{1}$ Covariate $=$ processing weight was significant $(\mathrm{P}<0.05)$ for hide.

${ }^{2}$ Means on the same row with different letters differ significantly $(\mathrm{P}<0.05)$.

$L W$ ), stomach ( 4.05 vs. 3.42 of LW), feet (1.86 vs. $1.96 \%$ of $L W$ ) and kidneys ( 0.18 vs. $0.16 \%$ of $L W$ ). The differences among breeds for the heart and tail weight were not significant.

At the same processing weight, cattle breed influenced the yield of certain by-products. Summed together, the Holsteins had 3.5\% more gastrointestinal tract, head and feet than the Zebu and Charbray bulls. Zebu and Charbray bulls had $2.22 \%$ and $1.25 \%$ more green hide than the Holstein bulls. In $550-\mathrm{kg}$ bulls, these differences represent a loss of 7.10 and $12.37 \mathrm{~kg}$ of yield for the Holsteins when compared to that of Zebu and Charbray bulls, respectively. These results support the customary practice of paying lower prices for Holstein bulls than for Charbray and Zebu bulls of the same LW to compensate for the greater amount of offal components and lesser carcass weight.

\section{Carcass traits}

Processing weights were not significantly different among the three breeds (Table 2). At the same processing weight, the Charbray and Zebu bulls' hot carcass weights (HCW) were 25.23 and $22.07 \mathrm{~kg}$ heaviex $(\mathrm{P}<0.05)$ than that of the Holstein bulls. No significant differences were found for HCW between Charbray and Zebu bulls $(\mathrm{P}>0.05)$. Nevertheless, loin eye areas were higher $(\mathrm{P}<0.05)$ for the Charbray than for the Zebu and Holstein bulls ( 85.03 vs. 76.77 and $\left.71.16 \mathrm{~cm}^{2}\right)$. These data agree with the results of Carroll et al. (1964) and Cole et al. (1963; 1964). 
TABLE 2.-Means for weight and physical measurements of carcass traits. ${ }^{-}$

\begin{tabular}{lccc}
\hline Items & Holstein & Charbray & Zebu \\
\hline Processing weight $(\mathrm{kg})$ & $559.94 \mathrm{a}$ & $568.92 \mathrm{a}$ & $574.70 \mathrm{a}$ \\
Hot carcass weight $(\mathrm{kg})$ & $304.26 \mathrm{~b}$ & $329.49 \mathrm{a}$ & $326.33 \mathrm{a}$ \\
Dressing \% & $54.17 \mathrm{~b}$ & $57.90 \mathrm{a}$ & $56.83 \mathrm{a}$ \\
Shrinkage $(\mathrm{kg})$ & $3.70 \mathrm{a}$ & $3.38 \mathrm{a}$ & $2.84 \mathrm{a}$ \\
Subcutaneous fat $(\mathrm{cm})$ & $0.25 \mathrm{a}$ & $0.28 \mathrm{a}$ & $0.35 \mathrm{a}$ \\
LEA (sq. cm) & $71.16 \mathrm{~b}$ & $85.03 \mathrm{a}$ & $76.77 \mathrm{~b}$ \\
Leg width $(\mathrm{cm})$ & $24.03 \mathrm{~b}$ & $26.03 \mathrm{a}$ & $25.85 \mathrm{a}$ \\
Leg length $(\mathrm{cm})$ & $53.00 \mathrm{a}$ & $48.90 \mathrm{~b}$ & $49.83 \mathrm{ab}$ \\
Frontquarter mean $(\mathrm{kg})$ & $86.48 \mathrm{a}$ & $92.17 \mathrm{a}$ & $90.36 \mathrm{a}$ \\
Frontquarter \% & 57 & 56 & 56 \\
Hindquarter mean $(\mathrm{kg})$ & $65.24 \mathrm{~b}$ & $71.83 \mathrm{a}$ & $70.92 \mathrm{a}$ \\
Hindquarter \% & 43 & 44 & 44 \\
\hline
\end{tabular}

'Covariate processing weight was significant $(P<0.05)$ for hot carcass weight and not significant $(P>0.05)$ for leg length and width. Covariate carcass weight was not signifcant $(P>0.05)$ for carcass shrinkage, loin-eye area, subcutaneous fat and dressing percentage. Covariate left-side carcass weight was significant $(\mathrm{P}<0.05)$ for front and hindquarter weight.

zMeans on the same row with different letters are significantly different ( $\mathrm{P}<0.05$ ).

Holstein bulls had a significantly longer hind leg $(53.0$ vs. $48.90 \mathrm{~cm}$; $\mathrm{P}<0.05$ ) than the Charbray, and a smaller round thickness ( 24.03 vs. 26.03 and $25.85 \mathrm{~cm} ; \mathrm{P}<0.05$ ) than the Charbray and Zebu bulls. Cole et al. (1963), Cole et al. (1964), García-de-Siles et al. (1977) and Kidwell and McCormick (1956) also observed longer carcasses in dairy type cattle and greater round thickness in British type cattle. These carcass measurements follow the generally accepted ideas of conformation for steers of typical beef, Zebu type, and dairy breeds of cattle.

No significant differences $(\mathrm{P}>0.05)$ were found among breeds for subcutaneous fat thickness (Callow, 1961; 'Truscott et al., 1976) and for the forequarter weight and percentage of left side, whereas dressing percentage, and hindquarter weight and percentage of left side were significantly higher $(\mathrm{P}<0.05)$ in the Charbray and Zebu bulls. Holstein carcasses showed the greatest shrinkage after 22 hours in the cooler $(8.13 \mathrm{~kg})$, followed by Charbray $(7.45 \mathrm{~kg})$, and Zebu $(6.26 \mathrm{~kg})$, but the differences were not significant $(\mathrm{P}>0.05)$. These results disagree with those of Carroll et al. (1964) and Cole et al. (1963) who reported that the hindquarter represented a greater percentage of the carcass in Holstein steers, and that dairy-type carcasses shrank in the cooler more than the carcasses of steers containing British or Brahman breeding. The use of bulls instead of steers and the small amounts of subcutane- 
ous fat $(\mathrm{P}>0.05)$ found in the present study may explain the lack of significant differences found for forequarter weight and percentage of left side and carcass shrinkage among breeds.

\section{Carcass composition}

After adjusting for differences in left-hot carcass weight (LHCW) and $\mathrm{LH}$ weight, Charbray and Zebu bulls presented higher $\mathrm{LH}$ weights, greater amounts of separable fat, and a higher muscle to bone ratio (P $<0.05$ ) than the Holstein bulls (Table 3 ). At the same LH weight, Charbray bulls exhibited significantly higher $(\mathrm{P}<0.05)$ amounts of muscle and a greater $(\mathrm{P}<0.05)$ muscle to bone+fat ratio than the Holstein and Zebu bulls. Holstein bulls had significantly higher $(\mathrm{P}<0.05)$ amounts of bone in the LH $(21.60$ vs, $16.63,17.46 \%)$ than Charbray and Zebu bulls, respectively. The mean weights of fascia/tendon and trimming were similar among breeds $(P>0.05)$.

These results are in agreement with previous studies by Cole et al. (1964), Kidwell and McCormick (1956), Thonney et al. (1987) and Truscott et al. (1976) that reported higher proportions of bone and lower proportions of fat for Holstein steer carcasses. Contrary to our findings, these authors also indicated that carcasses from Holstein steers had greater amounts of separable muscle. Higher percentages or total weights of muscle tissue have been reported in the carcass of Holstein steers when compared at the same physiological age or degree of fat-

TABLE 3.-Means for weight, and percentages of the left hindquarter component tissues and lean to bone and bone plus fat ratios.'

\begin{tabular}{lcrrrrrr} 
& \multicolumn{2}{c}{ Holstein } & \multicolumn{2}{c}{ Charbray } & \multicolumn{2}{c}{ Zebu } \\
\cline { 2 - 8 } Ltems & $\mathrm{kg}$ & $\%$ & $\mathrm{~kg}$ & $\%$ & $\mathrm{~kg}$ & $\%$ \\
\hline Left hindquarter & $65.23 \mathrm{~b} \mathrm{~b}^{2}$ & 42.41 & $71.83 \mathrm{a}$ & 43.67 & $70.92 \mathrm{a}$ & 44.80 \\
Muscle & $37.60 \mathrm{c}$ & 57.64 & $43.83 \mathrm{a}$ & 61.01 & $40.92 \mathrm{~b}$ & 57.69 \\
Bone & $14.08 \mathrm{a}$ & 21.60 & $11.94 \mathrm{~b}$ & 16.63 & $12.38 \mathrm{~b}$ & 17.46 \\
Fat & $3.33 \mathrm{c}$ & 5.11 & $5.20 \mathrm{~b}$ & 7.23 & $6.66 \mathrm{a}$ & 9.40 \\
Fascia and tendon & $2.23 \mathrm{a}$ & 3.42 & $2.57 \mathrm{a}$ & 3.59 & $2.33 \mathrm{a}$ & 3.28 \\
Trimming & $7.24 \mathrm{a}$ & 11.10 & $7.69 \mathrm{a}$ & 10.71 & $7.07 \mathrm{a}$ & 9.96 \\
Ratio:lean/bone & \multicolumn{2}{c}{$2.69 \mathrm{~b}$} & \multicolumn{2}{c}{$3.72 \mathrm{a}$} & \multicolumn{2}{c}{$3.37 \mathrm{a}$} & \\
Ratio:lean/bone+fat & \multicolumn{2}{c}{$2.28 \mathrm{~b}$} & & $2.74 \mathrm{a}$ & \multicolumn{2}{c}{$2.39 \mathrm{~b}$} & \\
\hline
\end{tabular}

${ }^{3}$ Covariate left hot carcass weight was significant $(\mathrm{P}<0.05)$ for left hindquarter weight. Covariate left hindquarter weight was significant $(\mathrm{P}<0.05)$ for bone and muscle weight and not significant for fat, fascia, trim, tendon weight and for the ratios of lean to bone and lean to bone plus fat.

"Means in the same row with different letters are significantly different $(\mathrm{P}<0.05)$. 
ness (Callow, 1961; Carroll et al., 1964), and even when compared at the same final weight against steers from British breeds (García-deSiles et al., 1977). The disagreement for separable muscle may reside in the fact that comparisons in this study involved Charbray and Zebu bulls, which are considered large late-maturing beef breeds, whereas the comparisons in the studies mentioned previously were made among Holstein and British breed beef steers (small medium-size and early maturing). Knapp et al. (1989) compared composite, English, and Holstein steers and concluded that the Holsteins had less fat trim but lower yields of major cuts.

The data collected reveal that at similar carcass weights Charbray and Zebu bulls have carcass traits and composition superior to that of the Holstein bulls. In the absence of early maturing breeds and of a high nutritional level to promote fat deposition, carcass differences point to the high proportion of lean $(\mathrm{P}<0.05)$ in the Charbray and of bone $(\mathrm{P}<0.05)$ in the Holstein bulls. In addition, the Charbray bulls were superior to the Zebu and Holstein in total excised muscle weight $(\mathrm{P}<0.05)$, the measure that determines the final economic value of the carcass. These results support evidence from the literature that indicates that the Charolais breed is superior in leanness to either the large dairy breeds, Zebu or typical British beef breeds.

\section{Muscles of the hindquarter}

Charbray and Zebu bulls showed significantly greater $(\mathrm{P}<0.05)$ amounts of the Semimembranosus, Psoas major, Longissimus dorsi and Semitendinosus muscles (Table 4) than Holstein bulls when compared at the same total muscle weight in the LH. The weight of the Biceps femoris muscle was significantly higher $(\mathrm{P}<0.05)$ in the Charbray bulls $(7.11 \mathrm{~kg})$, followed by the Zebu $(6.57 \mathrm{~kg})$ and the Holstein bulls $(5.73$ $\mathrm{kg})$. Charbray bulls presented a significantly higher $(P<0.05)$ weight for the Gluteus and the Cuadriceps femoris than the Zebu and Holstein bulls. No significant differences $(P>0.05)$ were found for the weight of the Gluteus and the Cuadriceps femoris between Holstein and Zebu bulls.

The results presented suggest that there were differences among breeds in muscle distribution of the $\mathrm{LH}$ as different weights and percentages were still observed when compared at the same total hindquarter muscle weight (Table 4). These findings may be the consequence of differences in degree of maturity among breeds since processing was performed at the same mean final weight. Adjusting breeds to the same total hindquarter muscle weight may not remove all the effects upon muscle weight that are due to genetic influences and 
TABLE 4.-Means for wetght and percentages of excised muscles of the left hindqrarter.'

\begin{tabular}{lcrrrrr} 
& \multicolumn{2}{c}{ Holstein } & \multicolumn{2}{c}{ Charbray } & \multicolumn{2}{c}{ Zebu } \\
\cline { 2 - 7 } Item & $\mathrm{kg}$ & $\%$ & $\mathrm{~kg}$ & $\%$ & $\mathrm{~kg}$ & $\%$ \\
\hline Semimembranosus & $7.58 \mathrm{~b}^{2}$ & 11.62 & $8.62 \mathrm{a}$ & 12.00 & $8.41 \mathrm{a}$ & 10.68 \\
Biceps femoris & $5.73 \mathrm{c}$ & 8.78 & $7.11 \mathrm{a}$ & 9.90 & $6.57 \mathrm{~b}$ & 9.26 \\
Gluteus & $4.64 \mathrm{~b}$ & 7.11 & $5.31 \mathrm{a}$ & 7.39 & $4.85 \mathrm{~b}$ & 6.83 \\
Cuadriceps femoris & $5.26 \mathrm{~b}$ & 8.06 & $5.86 \mathrm{a}$ & 8.15 & $5.25 \mathrm{~b}$ & 7.40 \\
Psoas-major & $1.74 \mathrm{~b}$ & 2.67 & $2.08 \mathrm{a}$ & 2.90 & $2.06 \mathrm{a}$ & 2.91 \\
Longissimus dorsi & $2.94 \mathrm{~b}$ & 4.50 & $3.88 \mathrm{a}$ & 5.41 & $3.48 \mathrm{a}$ & 4.91 \\
Semitendinosus & $2.18 \mathrm{~b}$ & 3.30 & $2.57 \mathrm{a}$ & 3.60 & $2.61 \mathrm{a}$ & 3.67 \\
\hline
\end{tabular}

'Covariate total muscle weight of the $\mathrm{LH}$ was significant $(\mathrm{P}<0.05)$ for all component muscles of the $L H$ with exception of the Psoas major $(P>0.05)$.

${ }^{2}$ Means in the same row with different letters are significantly different $P<0.05$ ).

degree of maturity at processing. After reviewing studies of muscle weight distribution, Berg and Butterfield (1968), Butterfield and Berg (1974) as well as García-de-Siles et al. (1977), working with Hereford and Holstein steers, concluded that muscle-weight distribution is not affected significantly by cattle type or breed when comparisons are made at the same relative degree of maturity. For practical reasons, comparisons in this study were conducted at the same final weight, hence, at a different physiological age and degree of fatness.

\section{LITERATURE CITED}

Armbruster, G., A. Y. M. Nour; M. L. Thonney and J. R. Stouffer, 1983. Changes in cooking losses and sensory attributes of Angus and Holstein beef with increasing carcass weight, marbling score or longissimus ether extraci. .l. Food Sci. 48:835-840.

Berg, R. T. and R. M. Butterfield, 1968. Growth patterns of bovine muscle, fat and bone. J. Anim. Sci. 27:611-619.

Butterfield, R. M, and R. T. Berg, 1974. Possibilities to change the muscle development of different parts of the body by breeding and feeding. P. 625-633. In Proceedings: First World Congress on Genetics Applied to Livestock Production, Madrid, Spain.

Callow, E. H., 1961. Comparative studies of meat. VII. A comparison between Hereford, Dairy Shorthorn and Friesian steers on four levels of nutrition. J. Agr: Sci. 56:265279.

Carpenter, J. W., A. Z. Palmer, W. G. Kirk, F. M. Peacock and M. Koger, 1961. Slaughter and carcass characteristics of Brahman and Brahman-Shorthorn crossbred steers. J. Anim. Sci. 20:336-340.

Carroll, F. D., M. T. Clegg and D. Kroger, 1964. Carcass characteristics of Holstein and Hereford steers. J. Agric. Sci, 62:1-6.

Cole, J. M., E. B. Ramsey and C. S. Hobbs, 1964. Effects of type and breed of British Zebu, and Dairy Cattle on production, carcass composition and palatability. $J$. Dairy Sci. 47:1138-1144. 
Cole, J. M., E. B. Ramsey, C. S. Hobbs and R. S. Temple, 1963. Effects of type and breed of British Zebu, and Dairy Cattle on production, palatability and composition. I. Rate of gain, feed efficiency and factors affecting market value. J. Animal Sci. 22:702-707.

García-de-Siles, J. L., J. H. Ziegler, L. L. Wilson and J. D. Sink, 1977. Growth, carcass and muscle characteristics of Hereford and Holstein steers, J. Animal Sci. 44:973984.

Harte, F. J. and D. Conniffe, 1967. Studics on cattle of varying growth potential for beef production. J. Growth rate, feed conversion efficiency, carcass yield and offals. Irish J. of Agricultural Res. 6:137-152.

Kidwell, J. F. and J. A. McCormick, 1956. The influence of size and lype on growth and development of cattle. J. Anim. Sci. 15:109-118.

Knapp, R. H., C. A. Terry, J. W. Savel], H. R. Cross, W. L. Mies and J. W. Edwards, 1989. Characterization of cattle types to meet specific beef targets. J. Animal Sci. 67:2294-2308.

Nour, A. Y. M., M. L. Thonney, J. R. Stoufer and W. R. C. White, Jr, 1981. Muscle, fat, and bone in scrially slaughter large dairy or small beef cattle fed corn or corn silage diets in one or two locations, J, Anim. Sci. 52:512-521.

Nour, A. Y. M., M. L. Thonney, J. R. Stouffer and W. R. C. White, Jr, 1983a. Changes in carcass weight and characteristics with increasing weigh J. Anim. Sci. 57:1154-1165.

Nour, A. Y. M., M. L. Thonney, J. R. Stouffer and W. R. C. White, Jr., 1983b. Changes in primal cut yield with increasing weight of large and small cattle. J. Anim. Sci. 57:1166-1172.

SAS Institute Inc., 1987. SAS/STAT Guide for Personal Computers, Raleigh, North Carolina.

Terry, C. A., R. H. Knapp, J. W. Edwards, W. L. Mies, J. W. Savell and H. R. Cross, 1990. Yields of by-products from diflerent cattle types. J. Animal Sci. 68:4200-4205.

Thorney, M. L., 1987. Growth, feed efficiency and variation of individually fed Angus, polled Hereford and Holstein steers. I. Animal Sci. 65:1-8.

Thonney, M. L., A. Y. M. Nour, J. R. Stouffer and W. R. C. White, Jr., 1.984. Changes in primal euts with increasing carcass weights in large and small cattle. Can. J. Animal Sci. 64:29-36.

Thonney, M. L.. T. C. Perry, G. Armbruster, D. H. Beermann and D. G. Fox, 1991. Comparison of steaks from Holstein and Simmental $\times$ Angus steers. d. Animal Sci. 69:4866-4870.

Truscott, T. G., C. P. Lang and N. M. Tulloh, 1976. A comparison of body composition and tissue distribution of Friesian and Angus steers. J. Agri. Sci., Camb. 87:1-14.

Ziegler, J. H., L. L. Wilson and D. S. Coble, 1971. Comparisons of certain carcass traits of several breeds and crosses of cattle. J. Animal Sci. 32:446-450. 